\title{
DÜBLIN
}

Technological University Dublin

ARROW@TU Dublin

Articles

School of Surveying and Construction

Management

2015-02-19

\section{Risk Management in Motorway PPP Projects: Empirical-based Guidelines}

\author{
Nunzia Carbonara \\ Polytechnic of Bari \\ Nicola Costantino \\ Polytechnic Institute of Bari, nicola.costantino@poliba.it \\ Louis Gunnigan \\ Technological University Dublin, louis.gunnigan@tudublin.ie
}

See next page for additional authors

Follow this and additional works at: https://arrow.tudublin.ie/beschrecart

Part of the Construction Engineering and Management Commons, and the Risk Analysis Commons

\section{Recommended Citation}

Carbonara, N. et al.(2015) Risk Management in Motorway PPP Projects: Empirical-based

Guidelines, Transport Reviews, Vol. 35, Is. 2. https://doi.org/10.21427/0znr-x792

This Article is brought to you for free and open access by the School of Surveying and Construction Management at ARROW@TU Dublin. It has been accepted for inclusion in Articles by an authorized administrator of ARROW@TU Dublin. For more information, please contact arrow.admin@tudublin.ie, aisling.coyne@tudublin.ie, gerard.connolly@tudublin.ie.

Funder: COST 


\section{Authors}

Nunzia Carbonara, Nicola Costantino, Louis Gunnigan, and Roberta Pellegrino 


\title{
Risk Management in Motorway PPP Projects: Empirical-based Guidelines
}

10

\author{
N. CARBONARA* , N. COSTANTINO* , L. GUNNIGAN** AND \\ R. PELLEGRINO*§
}

*Department of Mechanic, Mathematic and Management, Politecnico di Bari, Bari, Italy; **Dublin Institute of Technology, Dublin, Ireland

(Received 24 April 2014; revised 19 January 2015; accepted 24 January 2015)

ABSTRACT This paper deals with the topic of risk management in Public-Private Partnership $(P P P)$. The analysis of the related literature reveals that risks must be analyzed and managed on a context-specific approach, and that there is a lack of a comprehensive study on the appropriate risk mitigation strategies for each risk embedded in PPP projects. Focusing on the transport sector, based on the results of a Delphi survey, the paper provides guidelines for both public and private parties in defining a list of significant risks in PPP motorway projects, and identifying for them both the effective allocation and the suitable mitigation strategies. Results of the Delphi survey have been compared with the common practices on risk management applied in eight real motorway PPP projects.

\section{Introduction}

In recent years, the increasing need for the development of infrastructure and budgetary constraints in several developing and developed countries have led governments to seek new ways of financing facilities of public utility. One of the options is to involve private sector finance and expertise in the provision of public infrastructure and services through Public-Private Partnership (PPP). PPP can provide a variety of benefits to the government, by providing moreefficient, lower-cost and reliable public facilities; by improving the quality and efficiency of infrastructure services, and by promoting local economic growth and employment opportunities. However, at its heart, it remains the risk-management problem due to the high-degree risks affecting PPP projects that are usually characterized by many stakeholders, huge amounts of investments, long concession periods and so on. These risks are not borne by one party, but should be allocated to the party (public or private) who is best able to manage them.

In last years, an interesting volume of literature on risk management in PPP projects, both academic (Bing, Akintoye, Edwards, \& Hardcastle, 2005; Grimsey \& Lewis, 2004; Li, 2003; Ng \& Loosemore, 2007) and technical (see, for instance, technical reports provided on the US Federal Highway Administration web 


\section{N. Carbonara et al.}

site), has been developed. Yet, the analysis of the literature reveals that risks must be analyzed and managed on a context-specific approach, and that there is a lack of a comprehensive study on the more suitable risk mitigation strategies for each risk embedded in PPP projects. Focusing on a specific PPP sector, namely the transport sector, the present paper aims at filling this gap by providing guidelines for both public and private parties in defining a list of significant risks in PPP motorway projects, and identifying for them both the effective allocation and the suitable mitigation strategies.

With this aim, a Delphi survey is conducted with two panels of experts representative of both private and public parties, and various countries. Furthermore, the results of the Delphi survey have been compared with the common international practices on risk management drawn from a multiple-case study conducted on eight real cases of motorway PPP projects.

The paper is organized as follows. Next section briefly resumes the literature on risk management in PPPs, reviewing the contributions on risk identification, allocation and mitigation. Section 3 presents the research design. Section 4 discusses the Delphi results, while Section 5 compares them with the risk-management practices adopted in the analyzed case studies. Conclusions end the paper.

\section{Risk Identification, Allocation and Mitigation in PPP: A Literature Review}

PPP projects usually involve higher degree of risks than conventional procurement, since they are characterized by many stakeholders, a huge amount of investments and long concession periods (Wei-hua \& Da-shuang, 2006). Therefore, PPP projects involve not only risks that are project-related but also risks that depend on the inner characteristics of PPP as a procurement method. The importance of this theme justifies the development of several studies on risk management in PPP projects that can be clustered according to the conventional risk-management process: identification of risks, risk analysis and risk strategies (Tang, Shen, \& Cheng, 2010). Pellegrino, Vajdic, and Carbonara (2013) review the literature on risk identification and categorization in PPPs and divide studies into two groups: the first group comprises studies which focus on the nature of risks, whereas the second one contains studies which focus on the phase of project in which the risk typically appears.

Aoust, Bennett, and Fiszelson (2000) identify other categories of risks that are more likely to arise under a PPP project, that is, PPP-specific risks. They stem from the particular relationship between private and public entities whose economic interests are distinctively bundled in the project and can be grouped into three categories: fiscal risks, residual value risks and bidding risks.

A different risks' distinction categorizes risks as exogenous and endogenous. The former can be actively managed by changing behaviors, the latter are those where no party can take such active steps in order to reduce either threats or vulnerability (de Vries \& Yehoue, 2013).

To best allocate risks, two questions need to be answered (OECD, 2008): (1) which party is best able to prevent the risky event and (2) in the case where no party can prevent the risky event (i.e. an exogenous risk), which party is best able to manage the consequence of the adverse occurrence. To answer these questions, researchers have investigated the risk strategies adopted by the public and the private sectors. For example, Bing et al. (2005) conduct a survey to explore 
preferences in risk allocation in PPP and Public Finance Initiative (PFI) construction projects in the UK. Ke, Wang, Chan, and Lam (2010) have conducted a tworound Delphi survey with experienced practitioners, to analyze the risks and their preferred allocations for PPP projects in China. By furthering this study, $\mathrm{Ke}$, Wang, and Chan (2011) have conducted a series of face-to-face interviews to collect actual risk allocations in some completed Chinese PPP projects. By comparing the preferred and actual allocations and discovering the reasons behind the differences, they develop an equitable risk allocation schema applicable in China, and then evaluate the impact of risk misallocation (if any) on project performance (Ke, Wang, \& Chan, 2013). Another study involving an empirical questionnaire survey concerning PPP risk management in China was carried out by Chan, Yeung, Yu, Wang, and Ke (2011). Focusing on a total of 34 risk factors for PPP projects, they identify the major risks for the delivery of PPP projects in China and investigate the perceptions of industrial practitioners and academics on risk allocation. $\mathrm{Ng}$ and Loosemore (2007) discuss risk allocation in the private provision of public infrastructure. Medda (2007) develops an analytical model based on game theory to examine the process of risk allocation between the public sector and the private sector in transport PPP agreements. Carbonara, Costantino, and Pellegrino (2014a) develop a model for setting the concession period at a value able to satisfy both the private and public sectors while fairly allocating risks between them. Nisar (2007) discusses two strategies of transferring risks, that is, implicit and explicit transfer of risk in PPP/PFI contractual arrangements. Roumboutsos and Anagnostopoulos (2008) present the survey results regarding preferred risk allocation of prime stakeholders, that is, the public client, the construction companies and the financing institutes, and their respective risk ranking in the Greek PPP market. They found that the risks to be allocated to the public sector are all political and legal risks, as well as risks concerning archeological findings. Construction, operation, relationship and third-party risks are better handled by the private sector. Project finance risks and design risks, with the exception of availability of finance and permits, should also be assigned to the private sector. Finally, the public and private sectors preferably share macroeconomic, natural and social risks. Grimsey and Lewis (2002) state that successful risk allocation should take into account the differing (and conflicting) needs of the main participants involved in PPPs, that is, the procuring entity, the project sponsors and the senior lenders. Later, Grimsey and Lewis (2004), drawing on practical experience, present a risk matrix for the allocation of risks in PPP projects and apply it to a case study. In this matrix, no category is assigned in total to a specific party. Also, a number of standard risk allocation matrices have been produced to guide appropriate risk allocation in PPP projects (Milner, 2004; Smith, 1996).

All these studies recognized that there is not a list of risks and a risk allocation strategy that are applicable to all PPP projects and universally agreed to as the best. They found that the risks a PPP project may be exposed to are affected by a number of factors, such as the type and scale of the project, the country where the project is located and the sector. Therefore, the importance of a particular risk and the preferred risk allocation can differ from sector to sector and/or from country to country.

A less number of studies has dealt with risk mitigation strategies. Generally speaking, since risk is often defined as a measure of the probability and severity of adverse events (Lowrance, 1976), mitigation strategies are aimed at reducing 


\section{N. Carbonara et al.}

either the probability of occurrence of risk events, by acting on risk sources, or consequences of the risk event, when it occurs. Strategies traditionally adopted for risk mitigation in PPP are in the form of guarantees, insurance, possibility of changing contractual terms/clauses, etc. Such strategies can involve different parties, for example, the private party and the government, as in the case of revenue guarantee; the project company and the contractor who executes the works, as in the case of the majority of construction risks or the project company and the client, as in the case of "take and pay" or "take or pay" agreements. Most of the studies on risk mitigation strategies have focused on specific strategy to mitigate specific risk. In particular, there are a number of risk mitigation strategies for technical risks. These mitigation strategies are, in general, defined as clauses in the agreement or some forms of guarantees provided by one of the participants. For example, to mitigate construction risks and referring to standard construction contract, Pfeffer (2010) proposes a Guaranteed Maximum Price agreement, where the private party and contractor agree to cap the price; whereas referring specifically to project financing contract, Nevitt and Fabozzi (2005) propose completion guarantee extension to debt maturity, where the debt will be guaranteed until maturity in the event that completion is not achieved by a certain date.

170 Several strategies have been proposed to mitigate commercial risks, either in the form of guarantees, options (i.e. to expand or contract project capacity) or mechanisms. These mechanisms essentially present an agreement between the public and the private parties which defines rights and obligations if a certain event occurs. For example, with a revenue sharing mechanism, the public sector would have a right to claim the percentage of the revenue if the project internal rate of return exceeds a given value and the private party has an obligation to fulfil this claim (Gomez-Lobo \& Hinojosa, 2000); with minimum revenue guarantees, the concessionaire has the right to recourse to government to receive compensatory payments whenever the revenue is below a pre-established level (Carbonara, Costantino, \& Pellegrino, 2014b). Finally, specific mitigation strategies are proposed for economic and financial risks. For example, interest rate guarantee is released by government in order to ensure the PPP project's financial closure (Wibowo, 2004).

Studies focusing on risk identification and allocation in PPP projects agree that a comprehensive view of risks associated with PPPs cannot be developed given that the relevance of a risk and the preferred risk allocation is context-specific (sector and/or country).

Furthermore, the contemporary literature does not provide evidence on the more appropriate risk mitigation strategies for each risk embedded in PPP projects. This paper aims to fill this research gap. In particular, recognizing that the relevance of risks and the choice of the appropriate risk mitigation strategies depend on the specific PPP sector, we focus on the motorway sector and provide guidelines for both public and private parties in defining a list of significant risks in PPP motorway projects, and identifying for them both the effective allocation and the suitable mitigation strategies.

\section{Research Design}

The present study adopts a mixed-methods research that combines quantitative and qualitative research methods. Combining quantitative and qualitative 
research has several advantages, since it enables researchers to be more flexible and holistic in their investigative techniques (Onwuegbuzie \& Leech, 2005) Also, mixed-methods research addresses much more comprehensive research purpose than quantitative or qualitative research alone (Newman, Ridenour, Newman, \& DeMarco, 2003). Indeed, by combining quantitative and qualitative approaches within the same inquiry, investigators are able to probe further into a matter and to use one method to enhance the interpretation of findings stemming from the other method.

In our study, the mixed-methods strategy of inquiry is a sequential procedure, where the study begins with quantitative methods, the Delphi survey, and follows up with a qualitative method involving exploration with a few cases, multiplecase analysis.

Being aware that a number of contextual factors are likely to influence potential risks, their allocation and mitigation, we chose the case study approach, since it takes into account these contextual factors much more than the quantitative research alone (Yin, 1993).

\subsection{Delphi Methodology}

220 The research uses a Delphi technique for primary data collection. The Delphi technique is a method of eliciting and refining group judgments. It is a widely used and accepted method for achieving convergence of opinions concerning realworld knowledge by using a series of questionnaires to collect data from a panel of selected subjects. Contrarily to other research techniques used to collect expert judgments and opinions, such as focus group, nominal group, survey and semi-structured interview, with the Delphi method there is no need for participants to meet up and, hence, it is a relatively inexpensive method of gaining responses. It also allows the involvement of participants from disparate geographical areas, which are generally contacted by e-mail, thus facilitating international research. Furthermore, the Delphi method overcomes some problems of group interaction and does not allow individuals to dominate the discussion (van Teijlingen, Pitchforth, Bishop, \& Russell, 2006).

The Delphi method employs multiple iterations to reach a consensus of opinion concerning a specific topic (Hsu \& Sandford, 2007). Three main critical aspects have to be dealt with when adopting the Delphi technique.

The first concerns the sampling, namely the choice of the number of participants and the profile of the panel of experts. Witkin and Altschuld (1995) note that the approximate size of a Delphi panel is generally under 50. Ludwig (1997) documents that the majority of Delphi studies have used between 15 and 20 respondents. Considering factors such as the availability of resources and the expertise of panellists, Armstrong (1985) recommends group size of $n=5$ to $n=20$. In sum, the size of Delphi subjects is variable (Delbecq, Van de Ven, \& Gustafson, 1975), obviously the larger the sample size, the greater the generation of data, which in turn influences the amount of data analysis to be undertaken. This will lead to issues of data handling and potential analysis difficulties, particularly if employing a qualitative first-round approach.

The second critical aspect refers to the consensus level. Unanimity is not required in the Delphi technique; instead, a consensus level has to be predetermined. Dajani, Sincoff, and Talley (1979) suggest that consensus is achieved when there is the majority of agreement on an item, that is, at least $51 \%$ of the 


\section{N. Carbonara et al.}

respondents are in agreement, Sumsion (1998) recommends 70\%, while Green, Jones, Hughes, and Willimas (1999) opt for $80 \%$. Alternatively, Scheibe, Skutsch, and Schofer (1975) question the value of using percentage measures, suggesting that the stability of the response through a series of rounds is a more reliable indicator of consensus. However, measuring the percentage of votes that fall within a prescribed range is a common approach to assess consensus (Bobeva \& Day, 2005).

The third issue concerns the number of rounds that depends on the amount of time available, whether the researcher has indicated the Delphi sequence with one broad question or with a list of questions, and consideration of levels of sample fatigue. The literature demonstrates that three iterations are often sufficient to collect the needed information and to reach a consensus in most cases (Brooks, 1979; Custer, Scarcella, \& Stewart, 1999; Cyphert \& Gant, 1971; Green et al., 1999; Ludwig, 1997; Rowe \& Wright, 1999). A criterion generally used to set when to stop the procedure is based on the consensus level. The researcher must be aware of what the definition of "consensus" is in relation to the study's findings (Williams $\&$ Webb, 1994). If, for example, only those opinions that received over $50 \%$ agreement in round two were fed back to respondents in round three, this may bias the range of opinions from successive rounds. Outside factors such as limited resources may also influence the level of consensus selected by the researcher.

The three discussed issues can affect the validity of the Delphi results. The literature suggests that a valid approach to check the robustness of the findings is to undertake a Delphi study on two panels, where feedback is not exchanged between the two panels. The similarity of the two panels independently developed findings would prove the validity of the results (Ono \& Wedemeyer, 1994; Woudenberg, 1991).

\subsubsection{Questioned research topics: risks and risk mitigation strategies for PPP} projects. In the present research, each expert was asked to anonymously express his/her perception on the relevance of risks; the preferred risk allocation between public and private sectors and the suitability of specific strategies in mitigating risks, focusing on the motorway infrastructure sector in Europe, using a Likert scale. Key risks and risk mitigation strategies to be rated have been identified from the literature.

In particular, based on the literature review resumed in Section 2 (Aoust et al., 2000; Beidleman, Fletcher, \& Veshosky, 1990; Li, 2003; Thomas, Kalidindi, \& Ananthanarayanan, 2003; Tiong, 1990), a total of 22 risks associated with PPP projects were identified. Figure 1 shows these risks grouped by project phase. Tables 1-4 report the risk-management strategies for the most important risks in PPP projects. These have been sourced in much of the relevant PPP and nonPPP risk-management literature (see Pellegrino et al. (2013) for a comprehensive review).

3.1.2. Questionnaire design. The above-presented catalog of risks and mitigation strategies has been used to build the questionnaire used in the Delphi survey to explore participants' perceptions on: (i) the relevance of risks in the motorway PPP projects; (ii) the preferred risk allocation between public and private sectors and (iii) the suitability of specific strategies in mitigating risks.

The questionnaire was divided into five parts. With the aim of making uniform the interpretation of risks used in the questionnaire, the first part provides a description of each risk associated with PPP projects. The second part comprises 


\begin{tabular}{|c|c|c|c|}
\hline $\begin{array}{c}\text { PROJECT } \\
\text { DEVELOPMENT PHASE }\end{array}$ & $\begin{array}{c}\text { CONSTRUCTION } \\
\text { PHASE }\end{array}$ & OPERATION PHASE & TRANSFER PHASE \\
\hline $\begin{array}{l}\text { - Pre-investment risk } \\
\text { - Site risks } \\
\text { - Land use and } \\
\text { acquisition/resettlement } \\
\text { and rehabilitation risk } \\
\text { - Site condition } \\
\text { - Site preparation } \\
\text { - Financial closure risk } \\
\text { (project finance) } \\
\text { - Design risk }\end{array}$ & $\begin{array}{l}\text { - Construction risks } \\
\text { - Cost overrun } \\
\text { - Delay in completion } \\
\text { - Failure to meet } \\
\text { performance criteria }\end{array}$ & $\begin{array}{l}\text { - Operating risks } \\
\text { - Operating cost overrun } \\
\text { - Delays or interruption } \\
\text { in operation } \\
\text { - Shortfall in service } \\
\text { quality } \\
\text { - Revenue risks } \\
\text { - Changes in taxes/tariff } \\
\text { - Demand/usage risk }\end{array}$ & - Asset service level risks \\
\hline \multicolumn{4}{|c|}{ PROJECT LIFE CYCLE } \\
\hline $\begin{array}{l}\text { - Financial risks } \\
\text { - Interest rate increase } \\
\text { - Inflation } \\
\text { - Exchange rate } \\
\text { - Debt servicing risk }\end{array}$ & & $\begin{array}{l}\text { - Force majeure risks } \\
\text { - Regulatory/political risk } \\
\text { - Changes in legislation } \\
\text { - Political interference }\end{array}$ & \\
\hline
\end{tabular}

Figure 1. Risks in PPP projects by phase.

Table 1. Mitigation strategies for risks in the project development phase

Risk category Risk mitigation strategy

1. Pre-investment risk

2.2 Site condition

2.3 Site preparation

\section{Financial closure risk (project finance)}

4. Design risk

2. Site risks

2.1 Land use and acquisition/ resettlement and rehabilitation risk

- Provision for refunding the bidding cost by government

- Conditional bidding allows for setting certain logical conditions to be met before a bid is placed

- Detailed market analysis before bidding so that the investment will be made only if the market conditions indicate a good scenario

- Bid as a consortium involving two or more buyers

- Compensation clause in concession agreement

- Provision for increase in construction/concession time

- Contingency fund for increased land cost

- Exit clause in concession agreement

- Clause of effective start date and contingent effective start date in concession

- Site inspections and testing

- Government can commission contamination reports, given that government should also have greatest knowledge of the past uses of its site

- Provision for alternate promoter/lender

- Provisions for grant/subsidy from government

- Alternate technology for cost reduction in case of nonavailability of full debt: choose a technology less expensive than the original one in order to decrease the amount of debt required

- Defect liability clause in contract 


\section{N. Carbonara et al.}

Table 2. Mitigation strategies for risks in the construction phase

5. Construction risks

5.1 Cost overrun

5.2 Delay in completion

5.3 Failure to meet performance criteria (quality, innovation,...)

Risk mitigation strategy

- The sponsor or investors must agree to come up with the additional capital

- Contingency fund is a percentage assigned to the budget for overruns or unforeseen costs

- Fixed price (lump sum) contracts: the contractor/ construction company agrees to do the described and specified project for a fixed price

- Cost-plus Fee Contract: the owner/concessionaire agrees to pay the cost of all labor and materials plus an amount for contractor/construction company overhead and profit (often a set monthly fee or a fee based on a percentage of the cost of the work)

- Guaranteed Maximum Price agreement: an owner/ concessionaire and contractor/construction company can agree to cap the price once the project's design is substantially complete. Thus, a contractor who exceeds the capped amount is responsible for the difference, and if the total cost of the project is below the capped cost, the owner and contractor often agree to a "shared savings" benefit

- The sponsors provide an escrow account containing sufficient funds to complete the project

- Take out of lenders: the loan agreement can require the sponsor to purchase the asset and take out the lenders if the project is not completed and operating according to specification by a certain date

- Completion guarantee extension to debt maturity guarantees that debt will be guaranteed until maturity in the event that completion is not achieved by a certain date

- Completion/performance guarantees insure against financial loss from a delay in project completion attributable to specified causes, such as a failure of a party to perform on time

- Penalties or liquidated damages state an amount or rate calculated in advance, usually payable by the contractor/ construction company, for a delay to a project or performance failure. It is usually expressed in the contract as a fixed sum, daily or weekly rate

- Supply guarantee: the contractor/construction company insures himself/herself that the supply (i.e. material or equipment) will be available where it is needed, when it is needed

- Performance guarantees are forms of financial security provided by a party to secure the performance of the contractual obligations of the other. It usually provides for a monetary amount that may be called upon by the beneficiary of the guarantee in the event of a failure of the contractor/construction company to perform its obligations under the contract 
Table 3. Mitigation strategies for risks in the operation phase

Risk category Risk mitigation strategy

6. Operating risks

6.1 Operating cost overrun

6.2 Delays or interruption in operation

\subsection{Failure to meet service quality}

7. Revenue risks

7.1 Changes in taxes, tariffs

\subsection{Demand/usage risk}

- Maintenance bonds

- Maintenance reserves

- Fixed price and fixed duration operation contracts

- Insurance for accidents and clean-up operations

- Fixed price and fixed duration operation contracts

- Retainage accounts (for contractor/construction company default)

- Performance guarantees from operator

- Proven technology for operation and toll collection

- Warranties for hidden defects

- Performance bonus

- Tariff guarantees

- Traffic/revenue guarantee

- Defer payments of the concession fees

- Revenue sharing mechanism: the government has a right to claim the certain percentage of the revenue if the rate of return on the project's investment is above a specified value

- Revenue distribution mechanism: the government provides a guarantee of extra revenues. In turn, the concessionaire will make additional investments in the project and the concession will end when the guaranteed value of revenue is collected

- Least present value of revenue mechanism: the concession ends when a specified level of LPVR (least present value of the accumulated revenues) had been reached

- Defer payments of the concession fees

- Expand project capacity

- Contract project capacity

- Minimum revenue guarantee

- Usage guarantee

Table 4. Mitigation strategies for risks in the project life cycle

\begin{tabular}{ll}
\hline Risk category & \multicolumn{1}{c}{ Risk mitigation strategy } \\
\hline 8. Asset Service level risks & - Option to abandon for salvage value \\
9. Financial risks & - Interest rate guarantee, futures, options and swaps \\
9.1 Interest rate increase & - Adjust concession price; debt guarantee \\
9.2 Inflation & - Compensation payment \\
& - Inflation caps/floors \\
9.3 Exchange rate & - Exchange rate guarantee \\
9.4 Debt servicing risk & - Provision for revenue shortfall loan from government \\
& - Debt reserve accounts \\
& - Government indemnities for force majeure; suspending clauses \\
10. Force majeure risks & - Compensation from government \\
11. Regulatory/political risks & - Government assurances \\
& - Offshore escrow account \\
& - Extension of concession \\
& Compensation clauses from government
\end{tabular}


questions about the respondents' background. The third part is designed to evaluate the relevance of risks in the motorways sector. To do this, according to traditional method for evaluating risks, participants were asked to express their opinion about both the probability of risk occurrence and the risk impact on the project when it occurs. A five-point Likert scale is used as a measurement scale. Regarding the probability of occurrence and impact, the five-point Likert scale represents $1=$ very low, $2=$ low, $3=$ average, $4=$ high and $5=$ very high, with " 1 " responding to "almost never occurring" / "almost no impact" to "5" corresponding to "almost certainty" / "heavy losses", respectively. Respondents can also select "not applicable" (N/A) when not sure about the score.

The fourth part concerns the risk allocation. A three-point Likert scale is used to measure how participants perceive the allocation among contracting parties, with $1=$ mainly allocated to the public sector, 2 = equally shared between the public and private sectors and $3=$ mainly allocated to the private sector.

The last part of the questionnaire provides a list of risk mitigation strategies and registers how participants consider each mitigation strategy suitable for mitigating risks in the motorways sector. A five-point Likert scale is used, where $1=$ strongly suitable, $2=$ suitable, $3=$ neutral, $4=$ unsuitable and $5=$ strongly unsuitable. For all the questions, we ask the participants to justify their choices.

3.1.3. Procedure. To strengthen the robustness of the findings, we have conducted the Delphi survey with two groups, that are independent, namely, feedback is not exchanged between the two groups, and differently sized, with the second double of the first. The similarity of the two groups' findings would prove the validity of the results.

The target survey respondents belong to three categories: (i) practitioners in the public sector, (ii) practitioners in the private sector and (iii) experts who have experienced PPP projects with different roles, namely bank or financial advisors, users, academics and consultants. For each category, we have identified and invited to participate in the Delphi procedure 5 experts for the first panel and 10 for the second. Therefore, the initial size of the panels 1 and 2 was, respectively, 15 and 30. Two primary criteria were devised to identify the eligible participants for this survey: (1) having extensive working experience in PPPs (in fact respondents have at least 5 years of experience in PPPs) and (2) having been involved in motorway PPP projects.

Before running the procedure with the two groups of experts, a pilot test has been run on a small group of experts whose selection is based on their availability to go through the procedure and to provide a detailed feedback on the clarity of the questions.

490 The result of the first-round survey was consolidated and presented in the second-round questionnaire. By doing so, the respondent could see how his/ her choice is, compared with the mean value of the rest of experts. She/he could change her/his mind or to maintain her/his original view in the secondround survey.

495 Once we have reached the $70 \%$ of consensus level on the scores above average $(4-5)$, below average (1-2) and average (3), for the $70 \%$ of the questions in each part of the questionnaire, we stopped the procedure. Notice that, as for the analysis of results, we have considered and reported all the responses where the majority of opinion (51\% agreement among respondents) has been reached, since considered representative of the panel opinion. 


\subsection{Multiple-case Analysis}

Multiple-case study is used to study how risk is managed in real motorway PPP projects, in order to seek convergence and corroboration of findings stemming from the Delphi study. In fact, a case-based research method allows in depth, multi-faceted explorations of complex issues in their real-life settings (Yin, 2009). Also, case studies allow researchers to learn about the state of the art and to generate or test theories from practice (Benbasat, Goldstein, \& Mead, 1987), thus having high validity with practitioners (Voss, Tsikriktsis, \& Frohlich, 2002).

We adopt a multiple-case study approach in order to make comparison across cases. Being aware that the decision on how to select the cases is a very important issue, we have selected eight motorway PPP projects that reflect different contexts and have been carried out by following the same protocol of investigation. The selected cases have been developed within the COST Action TU1001 on Public Private Partnerships in Transport: Trends and Theory (Roumboutsos, Farrell, Liyanage, \& Macario, 2013). This choice is convenient because of the set of few cases, representative of different and heterogeneous contexts, and offers the possibility of making comparisons among countries and drawing relevant results.

\section{Delphi Survey Findings}

As detailed in Section 3.1.3, the invitation to participate in the survey was sent to 15 experts for the first panel and 30 for the second panel, while 11 experts for the first panel and 10 experts for the second one actually accepted the invitation to participate and completed the Delphi procedure. Table 5 shows the background information of the respondents. Notice that, the panel experts have been involved in a number of PPP projects, located in different countries, related to different transport modes and their background covers more than one field, that is why the total number reported in the rows 2, 3 and 4 of Table 5 exceeds 11 and 10 for panel 1 and 2, respectively. Consensus for panel 1 was achieved after the first round, while the second Delphi panel required two rounds for consensus to be achieved. The administration of the Delphi study was completed in about 18 months: the Delphi survey for panel 2 was carried out from March to June 2013, for panel 1 from May to November 2014.

535 Table 6 shows the assessments provided by the experts of the two panels on the probability of risk occurrence and the risk impact on the project, reporting only the answers where a $51 \%$ agreement among respondents has been reached. We label the scores below average (1-2), average (3) and above average (4-5) for the probability as Unlikely, Likely and Very Likely, respectively, and for the impact Minor, Moderate and Major, respectively.

As shown in Table 6, among the 22 risks listed in the questionnaire, panel 1 has reached consensus for 19 risks and panel 2 for 18 risks, while 17 of the 22 risks $(77 \%)$ show a majority opinion $(>50 \%)$ for both panels.

In order to define a list of significant risks in PPP motorway projects, we have considered both the probability of risk occurrence and the risk impact on the project if a risk event occurs. Figure 2 shows the Risk Probability-Impact Matrix where the probability of occurrence is plotted on the $y$-axis and the risk impact on the $x$-axis.

The matrix includes 17 of 22 risks listed in the questionnaire, which are those showing a majority opinion $(>50 \%)$ for both panels. The two panels have 
Table 5. Background information of the experts

\begin{tabular}{|c|c|c|c|c|c|c|c|}
\hline Perspective & Public sector & Private sector (partner) & $\begin{array}{l}\text { (1) Perspective of the ex } \\
\text { Banking/financing institution }\end{array}$ & Venture capitals & User of services & Academic & Consultant \\
\hline Panel 1 & 3 & 3 & - & - & - & 2 & 3 \\
\hline Panel 2 & 7 & 2 & - & - & - & - & 1 \\
\hline \multicolumn{8}{|c|}{ (2) Transport modes of the PPP that the expert has been involved with } \\
\hline Mode & Motorways & Ports & Airports & Urban transport & Rail & & \\
\hline Panel 1 & 11 & 6 & 1 & - & 2 & & \\
\hline Panel 2 & 10 & 3 & $1>$ & 3 & - & & \\
\hline \multicolumn{8}{|c|}{ (3) Country of the PPP project that the expert has been involved with } \\
\hline Country & Europe & North America & South America & & & & \\
\hline Panel 1 & 8 & 3 & 1 & & & & \\
\hline Panel 2 & 10 & - & - & & & & \\
\hline \multicolumn{8}{|c|}{ (4) Background of the expert } \\
\hline Field & Economics & Engineering & Financing & & ing & & \\
\hline Panel 1 & 3 & 6 & 3 & & & & \\
\hline Panel 2 & 5 & 6 & 2 & & & & \\
\hline \multicolumn{8}{|c|}{ (5) Years of experience in PPPs of the expert } \\
\hline Years & & $6-10$ years & & 15 years & & Ove & years \\
\hline Panel 1 & & 3 & & 3 & & & \\
\hline Panel 2 & & 6 & & 4 & & & \\
\hline
\end{tabular}


Table 6. Summary of the risk assessment

\begin{tabular}{lllll}
\multicolumn{2}{c}{ Probability } & & \multicolumn{2}{c}{ Impact } \\
\cline { 1 - 3 } Panel 1 & Panel 2 & & Panel 1 & Panel 2 \\
\hline
\end{tabular}

Risk category

2. Site risks

2.2 Site condition

2.3 Site preparation

3. Financial closure risk (project finance)

610 4. Design risk

5. Construction risks

5.1 Cost overrun

5.2 Delay in completion

5.3 Failure to meet performance criteria

(quality, innovation, ...)

615 6. Operating risks

6.1 Operating cost overrun

6.2 Delays or interruption in operation

6.3 Failure to meet service quality

7. Revenue risks

7.1 Changes in taxes, tariffs

7.2 Demand/usage risk

8. Asset Service Level risks

9. Financial risks

9.1 Interest rate increase

9.2 Inflation

9.3 Exchange rate

6259.4 Debt servicing risk

10. Force majeure events

11. Regulatory/political risks

11.1 Changes in legislation

11.2 Political interference

\begin{tabular}{|c|c|c|c|}
\hline Unlikely & - & Moderate & - \\
\hline Unlikely & Unlikely & Moderate & Moderate \\
\hline Likely & Likely & Major & Major \\
\hline Unlikely & Unlikely & Moderate & Moderate \\
\hline Likely & Likely & Moderate & Moderate \\
\hline Unlikely & Unlikely & Moderate & Moderate \\
\hline Unlikely & Unlikely & Moderate & Moderate \\
\hline - & Unlikely & - & Moderate \\
\hline Unlikely & Unlikely & Minor & Minor \\
\hline Unlikely & Unlikely & Minor & Minor \\
\hline Likely & Unlikely & Moderate & Minor \\
\hline Very likely & Very likely & Major & Major \\
\hline Unlikely & & Moderate & - \\
\hline Very likely & Very likely & Major & Major \\
\hline Unlikely & Likely & Moderate & Major \\
\hline Unlikely & Unlikely & Minor & Minor \\
\hline Likely & Likely & Major & Major \\
\hline Likely & Likely & Major & Major \\
\hline Unlikely & Unlikely & Major & Major \\
\hline Unlikely & Unlikely & Moderate & Moderate \\
\hline
\end{tabular}

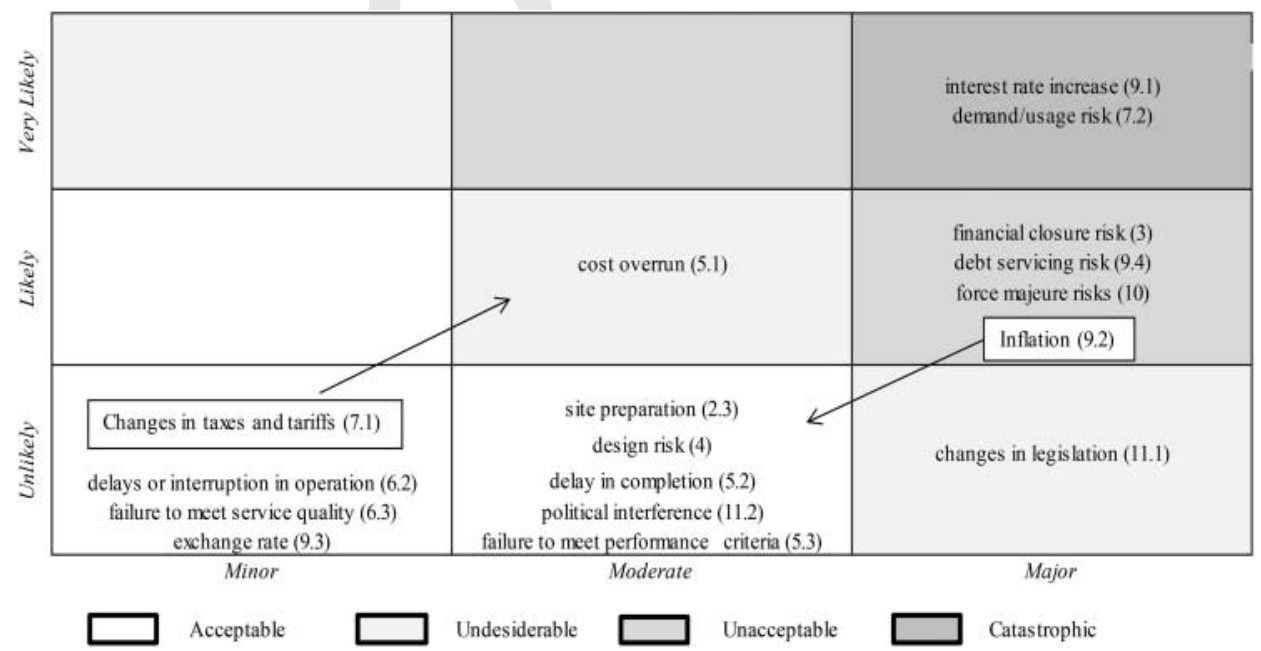

Figure 2. Risk probability-impact matrix. 
provided a different assessment to the probability and the impact of some of those risks. Therefore, we build the matrix on the judgment expressed by panel 2 and use the arrows where the assessment of panel 1 differs.

The matrix shows that the two panels express the same opinion for 15 risks. Among these, a total of eight risks are classified as acceptable, two risks as undesirable, a total of three risks as unacceptable and two risks are classified as catastrophic by both panels.

Within this list of risks, considering as key risks those classified by both panels as unacceptable, undesirable and catastrophic, we identify seven most significant risks in PPP motorway projects. Notice that other two risks can be considered critical since one of the two panels retains it as key: panel 1 includes changes in taxes and tariffs (7.1), while panel 2 inflation (9.2). That is why we include these risks in the further analysis.

Looking at the list of key risks, it is interesting to note that five out of nine are risks that span the entire life cycle of the PPP project (Figure 1), hence they are perceived as critical by the experts since they constantly threaten the project success. For all the other key risks of the list, except for financial closure risk, the judgments expressed by the experts are driven by the characteristics of the specific sector we focused on, namely the motorway sector. In fact in the motorway sector, given the complexity and the uncertainty affecting the construction phase, actual costs are likely to be higher than the budgeted costs. Furthermore, revenue risks are perceived as key because of the great uncertainty that makes an accurate estimation of the future level and composition of traffic volumes a difficult task. At the same time, a wrong estimation of traffic forecasts strongly affects the profitability of the project, especially if direct user charges, such as tolls, are the main source of cash flow for the PPP project.

As for the risk allocation, a consensus level higher than $51 \%$ has been reached for all the questions by both panels. Focusing on the identified key risks, the panels agree that financial closure risk, cost overrun, interest rate increase, inflation and debt servicing risk should be allocated to the private sector; while force majeure risks, changes in legislation and demand/usage risk should be equally shared between the two parties (Table 7). Results are coherent with the widely accepted principle of allocating risks to the party best able to manage

Table 7. Key risks allocation matrix

\begin{tabular}{|c|c|c|c|}
\hline 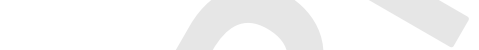 & Private & Equally shared & Public \\
\hline $\begin{array}{l}\text { 3. Financial closure risk (project finance) } \\
\text { 5. Construction risks }\end{array}$ & $\checkmark$ & & \\
\hline 5.1 Cost overrun & $\checkmark$ & & \\
\hline 7. Revenue risks & & & \\
\hline 7.1 Changes in taxes, tariffs & & $\checkmark$ & \\
\hline 7.2 Demand/usage risk & & $\checkmark$ & \\
\hline 9. Financial risks & & & \\
\hline 9.1 Interest rate increase & $\checkmark$ & & \\
\hline 9.2 Inflation & $\checkmark$ & & \\
\hline 9.4 Debt servicing risk & $\checkmark$ & & \\
\hline 10. Force majeure risks & & $\checkmark$ & \\
\hline 11. Regulatory/political risks & & & \\
\hline 11.1 Changes in legislation & & $\checkmark$ & \\
\hline
\end{tabular}


them. Even for the other risks not listed in the table, namely those judged acceptable, the answers on their allocation seem to be based on the same principle. For example, political interference is the only risks allocated to the public sector.

Finally, as concerns the identification of the suitable mitigation strategies, Table 8 shows the mitigation strategies judged suitable (S) (either score 5 or 4 in the Likert scale) by both panels for the identified key risks. Notice that we have also retained strategies judged suitable by one panel and neutral by the other, being the score "Neutral" (N) not discriminant.

The two panels have expressed the same opinion on more than half of the risk mitigation strategies listed in Table 8. As for the others, it does not emerge a divergence of opinion since "Neutral" does not mean unsuitability.

The results of the Delphi study show a significant convergence of opinions among the experts of the two panels on the identification, allocation and mitigation of key risks, although the different composition of the two panels in terms of experts perspective.

Table 8. Suitable mitigation strategies for key risks

\begin{tabular}{l} 
Risk category \\
\hline 3. Financial closure risk (project \\
finance) \\
5. Construction risks \\
5.1 Cost overrun
\end{tabular}

7. Revenue risks

7.1 Changes in taxes tariffs

7.2 Demand/usage risk
9. Financial risks

9.1 Interest rates increase

9.2 Inflation

9.4 Debt servicing risk

10. Force majeure risks

11. Regulatory/political risks

11.1 Changes in legislation
Risk mitigation strategy

Panel 1 Panel 2

- Provision for alternate promoter/lender

S

$\mathrm{S}$

- Additional capital

- Fixed price (lump sum) contracts

- Guaranteed Maximum Price agreement

- Escrow account to complete the project

- Take out of lenders

- Tariff guarantees

- Traffic/revenue guarantee

- Defer payments of the concession fees

- Revenue sharing mechanism

- Revenue distribution mechanism

- Least present value of revenue mechanisms

- Minimum revenue guarantee

- Usage guarantee

- Interest rate guarantee, futures, options and swaps

- Adjust concession price; debt guarantee

- Compensation payment

- Inflation caps/floors

- Flexible price formula to meet traffic revenue deficiencies

- Debt reserve accounts

- Government indemnities

- Compensation from government

- Government assurances

- Extension of concession

- Compensation clauses from government

S N

S N




\section{Risk Management in Practice: Delphi Results vs. Multiple-case Analysis}

The results of the Delphi survey are compared with the common practices on risk management applied in eight real road and motorway PPP projects. Cases range from conventional toll motorways in Greece through a road tunnel in the Netherlands financed by availability payments, to an airport access road built by the Flemish Government using a public sector corporate entity and a shadow Design-Build-Finance-Maintenance (DBFM) agreement. Table 9 synthetizes the main characteristics of the eight PPP projects.

The multiple-case study analysis provides interesting insights if compared with the Delphi survey results. As concerns the relevance of risks in PPP motorway projects, the cases confirm the experts' opinion for the revenue risks while do not report evidences on the criticality of interest rate risk. In particular, most of the analyzed cases show that the demand/usage risk has a severe impact on the project and remains one of the major issues driving the renegotiation process. The perception of the criticality of the revenue risks has induced in the A19 Dishforth Design-Build-Finance-Operation (DBFO) and in the M80 Stepps To Haggs DBFO projects to use shadow tolls as the mechanism for repaying the concessionaire, while in the BNRR M6 Toll project, to protect the concessionaire from drop of revenues in a period of economic decline, the special purpose vehicle (SPV) has a high degree of autonomy in how it sets the level of tolls, specifically the SPV is allowed to review tolls on a six-monthly cycle. In the Attica Tollway project, because sponsors considered that the road traffic levels and the tolls the users were prepared to pay were not enough to provide an adequate return on the investment, a strong financial help from the Greek Government was necessary. The traffic volume drop due to the Greek sovereign debt crisis has affected the demand risk both in the Ionia Odos Motorway and in the Olympia Odos Motorway projects as perceived by the private sector, and is expected to have a decisive role on the final renegotiated contract structure, mainly through the amendment of the toll revenue sharing mechanisms during the operational period.

Table 9. Projects overview

\begin{tabular}{|c|c|c|c|c|c|}
\hline Name & Country & Type & $\begin{array}{l}\text { Contract } \\
\text { duration }\end{array}$ & Budget & Source \\
\hline $\begin{array}{l}\text { A19 Dishforth } \\
\text { DBFO }\end{array}$ & UK & Brownfield & 30 years & GBP $29,4 \mathrm{M}$ & $\begin{array}{l}\text { Boles and Liyanage } \\
\text { (2013a) }\end{array}$ \\
\hline $\begin{array}{l}\text { Attica Tollway, } \\
\text { Athens Ring } \\
\text { Road }\end{array}$ & Greece & $\begin{array}{l}\text { Brownfield and } \\
\text { Greenfield }\end{array}$ & 25 years & Eur $1300 \mathrm{M}$ & $\begin{array}{l}\text { Halkias, Roumboutsos, } \\
\text { and Pantelia (2013) }\end{array}$ \\
\hline Coen Tunnel & $\begin{array}{l}\text { The } \\
\text { Netherlands }\end{array}$ & $\begin{array}{l}\text { Brownfield and } \\
\text { Greenfield }\end{array}$ & 30 years & Eur 571M & Voordijk (2013) \\
\hline $\begin{array}{l}\text { Ionia Odos } \\
\text { Motorway }\end{array}$ & Greece & $\begin{array}{l}\text { Brownfield and } \\
\text { Greenfield }\end{array}$ & 30 years & Eur $1200 \mathrm{M}$ & $\begin{array}{l}\text { Nikolaidis and } \\
\text { Roumboutsos (2013) }\end{array}$ \\
\hline BNRR M6 Toll & UK & $\begin{array}{l}\text { Brownfield and } \\
\text { Greenfield }\end{array}$ & 53 years & GBP 900M & $\begin{array}{l}\text { Liyanage and Boles } \\
\text { (2013) }\end{array}$ \\
\hline $\begin{array}{l}\text { M80 Stepps to } \\
\text { Haggs DBFO }\end{array}$ & UK & $\begin{array}{l}\text { Brownfield and } \\
\text { Greenfield }\end{array}$ & 33 years & $\begin{array}{l}\text { GBP } \\
\qquad 251,4 \mathrm{M}\end{array}$ & $\begin{array}{l}\text { Boles and Liyanage } \\
\text { (2013b) }\end{array}$ \\
\hline $\begin{array}{l}\text { Olympia Odos } \\
\text { Motorway }\end{array}$ & Greece & $\begin{array}{l}\text { Brownfield and } \\
\text { Greenfield }\end{array}$ & 30 years & Eur $2200 \mathrm{M}$ & $\begin{array}{l}\text { Roumboutsos and } \\
\text { Nikolaidis (2013) }\end{array}$ \\
\hline $\begin{array}{l}\text { Via-Invest } \\
\text { Zaventem }\end{array}$ & Belgium & $\begin{array}{l}\text { Brownfield and } \\
\text { Greenfield }\end{array}$ & 30 years & $\begin{array}{l}\text { Eur } \\
219,85 \mathrm{M}\end{array}$ & $\begin{array}{l}\text { van den Hurk and Van } \\
\text { Gestel (2013) }\end{array}$ \\
\hline
\end{tabular}


As for the interest rate risk, the analysis of cases does not highlight any criticality on it that indeed is perceived as catastrophic by experts. This can be explained by noticing that after the financial crisis the interest rates constantly decrease in the countries where the cases are located.

805 As for the risk allocation, the practices adopted in the cases are not completely aligned with the opinion of experts involved in the Delphi survey (Table 10). Specifically, for the construction risks and financial risks we found a full coherence between the practices adopted in the real projects and the opinion of experts. In most of the analyzed cases, both types of risk are allocated to the private party 810 according to the opinion of experts. Differently, the allocation of the other risks, namely revenue, force majeur and regulatory/political risks, does not match with the results of the Delphi survey.

Particularly, in most of the analyzed projects, the revenue risks are allocated to the private party, while experts express the opinion that revenue risks should be equally shared. Actually, such a divergence is only apparent. In practice, in fact, the mitigation strategies usually adopted, namely revenue sharing mechanisms and/or strong financial support provided by the public sector in the form of guarantees, confirm that there exists a substantial risk sharing between the two parties.

Table 10. Projects' risk allocation matrix

\begin{tabular}{|c|c|c|c|}
\hline Risks & Private & Equally shared & Public \\
\hline Construction risks & $\begin{array}{l}\text { M80 Stepps-Haggs } \\
\text { Attica Tollway } \\
\text { Ionia Odos } \\
\text { BNRR M6 Toll } \\
\text { Olympia Odos } \\
\text { Via-Invest Zaventem }\end{array}$ & A19 Dishforth & Coen Tunnel \\
\hline Revenue risks & $\begin{array}{l}\text { A19 Dishforth } \\
\text { Attica Tollway } \\
\text { Coen Tunnel } \\
\text { Ionia Odos } \\
\text { BNRR M6 Toll } \\
\text { Olympia Odos }\end{array}$ & M80 Stepps-Haggs & Via-Invest Zaventem \\
\hline Financial risks & $\begin{array}{l}\text { A19 Dishforth } \\
\text { BNRR M6 Toll } \\
\text { M80 Stepps-Haggs } \\
\text { Attica Tollway } \\
\text { Ionia Odos } \\
\text { Olympia Odos }\end{array}$ & $\begin{array}{l}\text { Coen Tunnel } \\
\text { Via-Invest Zaventem }\end{array}$ & \\
\hline Force majeur risks & M80 Stepps-Haggs & Via-Invest Zaventem & $\begin{array}{l}\text { A19 Dishforth } \\
\text { Attica Tollway } \\
\text { Ionia Odos } \\
\text { BNRR M6 Toll } \\
\text { Olympia Odos } \\
\text { Coen Tunnel }\end{array}$ \\
\hline Regulatory/political risks & & M80 Stepps-Haggs & $\begin{array}{l}\text { A19 Dishforth } \\
\text { Attica Tollway } \\
\text { Ionia Odos } \\
\text { Olympia Odos } \\
\text { Via-Invest Zaventem } \\
\text { BNRR M6 Toll } \\
\text { Coen Tunnel }\end{array}$ \\
\hline
\end{tabular}


At the same time, those cases where the revenue risks have not been shared incurred in costly renegotiation processes, as for the Ionia Odos Motorway and Olympia Odos Motorway projects. Then, the common international practices actually confirm the experts' opinion. As for the allocation of force majeur and regulatory/political risks, in most of the analyzed cases these are borne by the public sector, while according to the experts they should be preferably equally shared. Such a result comes out of the negotiation process where the government, recognizing them out of the private party control, accepts to bear these risks to assure the long-term success of the PPP and indemnify the private sector against them. This confirms that mitigation strategies conventionally adopted to mitigate these risks are government indemnities, assurances and compensation, as pointed out by the experts involved in the Delphi survey.

\section{Conclusions}

One of the critical aspects that affects the success of a PPP project is the risk management. Recognizing that the relevance of risks, the establishment of an acceptable risk allocation scheme and the choice of the appropriate risk mitigation strategies depend on the specific PPP sector, we focus on the motorway sector. Based on the results of a Delphi survey, we define a list of significant risks in PPP motorway projects, prepare a practical risk allocation matrix and identify the appropriate strategies to mitigate each identified key risk.

The research findings indicate that the most critical risks in PPP motorway projects are both endogenous and exogenous to the project. As regards the first category, the most significant, for its high probability of occurrence and its high impact, is the demand/usage risk which is one of the revenue risks that occurs during the Operation phase. For this catastrophic risk, the two panels fully agree that it should be preferably allocated equally between the two parties, and that the suitable risks mitigation strategies are Revenue sharing mechanism and Revenue distribution mechanism. Other endogenous key risks, less severe than the previous one, are cost overrun and financial closure risk, classified as undesirable and unacceptable, respectively. The former occurs in the Construction phase and, coherently with its nature, the preferred risk allocation is to the private party. Multifarious strategies can be adopted to effectively mitigate this risk. The latter occurs during the project Development phase and, being related to the project financing, should be preferably allocated to the private party. The risk mitigation strategy judged suitable by the experts is the Provision for alternate promoter/lender.

The key risks exogenous to the project, due to factors outside the control of the project parties, can occur during the entire life cycle of the PPP project. Most of them depend on the economic/financial and institutional contexts where the project is developed while only one refers to force majeure events. Among these, financial risks should be preferably allocated to the private sector, and multifarious strategies can be adopted to effectively mitigate these risks. Regulatory and force majeure risks should be equally shared, the former can be mitigated through different strategies while, for the force majeure risks, the panels identify as suitable mitigation strategy the Government indemnities.

The results of the Delphi survey have been compared with the common practices on risk management applied in eight real road and motorway PPP projects. All the analyzed cases confirm that the demand risk is the one with the greater impact on the project and remains the major issues driving the renegotiation 
process. We found that this risk is mostly allocated to the private sector, but, in the practice, the public party protects the concessionaire by revenue shortfalls by using shadow tolls as mechanisms for repayment to the concessionaire or by allowing the concessionaire to increase tariffs so as to ensure that the project is self-financed, unless incurring into costly and extensive renegotiation processes between the two parties.

Contrarily, the analyzed cases do not report evidences on the criticality of interest rate risk, which is not considered as an issue in the countries where the cases are located, given the decreasing trend of the Interest rate in last years.

910 The research findings presented in this paper will support both the public and private sectors in understanding the key risks, establishing an effective risk allocation and adopting the most effective mitigation strategies. Main managerial implications of the study are informing the parties in the negotiation process so as to avoid costly renegotiation and in the more risky phases and activities of the project so as strengthening control and monitoring measures.

A major limitation of this study is that the guidelines are developed without considering the correlation among risks, that is, by assuming that each risk is independent of each other. This issue will be addressed in future work by investigating whether mitigation strategies conceived relatively to the separated risks are still effective once risks occur combined together.

Further researches will be carried out mainly in two directions. Firstly we intend to replicate the study for the other transport modes, thus providing comprehensive guidelines for risk management in transport PPP. Secondly, we intend to investigate if and how the global financial crisis impacts on the risk assessment and thus on the identification of the key risks in PPP motorway projects, their allocation and mitigation.

\section{Disclosure statement}

No potential conflict of interest was reported by the authors.

\section{References}

Armstrong, J. (1985). Long range forecasting: From crystal ball to computer. New York, NY: John Wiley \& Sons.

Aoust, J. M., Bennett, T. C., \& Fiszelson, R. (2000). Risk analysis and sharing: The key to a successful public-private partnership. In J. Y. Perrot \& G. Chatelus (Eds.), Financing of major infrastructure and public service projects: Public-private partnership (pp. 57-80). Paris: Éditions Lavoisier.

Beidleman, C. R., Fletcher, D., \& Veshosky, D. (1990). On allocating risk: The essence of project finance. Sloan Management Review, Spring, 31(3), 47-55.

Benbasat, I., Goldstein, D., \& Mead, M. (1987). The case research strategy in studies of information systems. MIS Quarterly, 11, 369-386.

Bing, L., Akintoye, A., Edwards, P. J., \& Hardcastle, C. (2005). The allocation of risk in PPP/PFI construction projects in the UK. International Journal of Project Management, 23, 25-35.

Bobeva, M., \& Day, J. (2005, April 21-22). Managing Delphi studies: A decision making toolkit. In A. Brown (Ed.), Proceedings of the 4th European conference on research methodology for business and management studies (pp. 55-66). Paris, France: Universite Paris-Dauphine.

Boles, C., \& Liyanage, C. L. (2013a). A19 Dishforth DBFO, England, UK. In A. Roumboutsos, S. Farrell, C. L. Liyanage \& R. Macario (Eds.), 2013 discussion papers. Part II Case Studies (pp. 21-27). Bari, Italy: Arti Grafiche Favia.

Boles, C., \& Liyanage, C. L. (2013b). M80 Haggs to Stepps, UK. In A. Roumboutsos, S. Farrell, C. L. Liyanage \& R. Macario (Eds.), 2013 discussion papers. Part II case studies (pp. 73-80). Bari, 
Brooks, K. W. (1979). Delphi technique: Expanding applications. North Central Association Quarterly, 54(3), 377-385.

Carbonara, N., Costantino, N., \& Pellegrino, R. (2014a). Concession period for PPPs: A win-win model for a fair risk sharing. International Journal of Project Management, 32, 1223-1232.

Carbonara, N., Costantino, N., \& Pellegrino, R. (2014b). Revenue guarantee in PPPs: A fair risk allocation model. Construction Management and Economics, 32(4), 403-415.

Chan, A. P. C., Yeung, J. F. Y., Yu, C. C. P., Wang, S. Q., \& Ke, Y. (2011). Empirical study of risk assessment and allocation of public-private partnership projects in China. Journal of Management in Engineering, 27(3), 136-148.

Custer, R. L., Scarcella, J. A., \& Stewart, B. R. (1999). The modified Delphi technique: A rotational modification. Journal of Vocational and Technical Education, 15(2), 1-10.

Cyphert, F. R., \& Gant, W. L. (1971). The Delphi technique: A case study. Phi Delta Kappan, 52, 272-273.

Dajani, J. S., Sincoff, M. Z., \& Talley, W. K. (1979). Stability and agreement criteria for the termination of Delphi studies. Technological Forecasting and Social Change, 13, 83-90.

Delbecq, A. L., Van de Ven, A. H., \& Gustafson, D. H. (1975). Group techniques for program planning. Glenview, IL: Scott, Foresman, and Co.

Gomez-Lobo, A., \& Hinojosa, S. (2000). Broad roads in a thin country: Infrastructure concessions in Chile. Policy Research Working Paper, No. 2279, World Bank, Washington, DC.

Green, B., Jones, M., Hughes, D., \& Willimas, A. (1999). Applying the Delphi technique in a study of GP's information requirements. Health and Social Care in the Community, 7(3), 198-205.

Grimsey, D., \& Lewis, K. K. (2004). Public private partnerships. Cheltenham: Edward Elgar.

Grimsey, D., \& Lewis, M. K. (2002). Evaluating the risks for public private partnerships for infrastructure projects. International Journal of Project Management, 20, 107-118.

Halkias, B., Roumboutsos, A., \& Pantelia, A. (2013). Attica Tollway, The Athens Ring Road, Greece. In A. Roumboutsos, S. Farrell, C. L. Liyanage \& R. Macario (Eds.), 2013 discussion papers. Part II case Studies (pp. 28-38). Bari, Italy: Arti Grafiche Favia.

Hsu, C., \& Sandford, B. A. (2007). The Delphi technique: Making sense of consensus. Practical Assessment, Research \& Evaluation, 12(10), 1-8.

van den Hurk, M., \& Van Gestel, K. (2013). Via-Invest Zaventem, Belgium. In A. Roumboutsos, S. Farrell, C. L. Liyanage \& R. Macario (Eds.), 2013 discussion papers. Part II case studies (pp. 90-100). Bari, Italy: Arti Grafiche Favia.

Ke, Y., Wang, S. Q., \& Chan, A. P. C. (2011). Equitable risks allocation of projects inside China: Analyses from Delphi survey studies. Chinese Management Studies, 5(3), 298-310.

Ke, Y., Wang, S. Q., \& Chan, A. P. C. (2013). Risk misallocation in public-private partnership projects in China. International Public Management Journal, 16(3), 438-460.

Ke, Y., Wang, S. Q., Chan, A. P. C., \& Lam, P. T. I. (2010). Preferred risk allocation in China's publicprivate partnership (PPP) projects. International Journal of Project Management, 28, 482-492.

Li, B. (2003). Risk management of public/private partnership projects (Unpublished PhD thesis). School of the Built and Natural Environment, Glasgow Caledonian University, Glasgow, Scotland.

Liyanage, C. L., \& Boles, C. (2013). M6 Toll BNRR, England, UK. In A. Roumboutsos, S. Farrell, C. L. Liyanage \& R. Macario (Eds.), 2013 discussion papers. Part II case studies (pp. 62-72). Bari, Italy: Arti Grafiche Favia.

Lowrance, W. W. (1976). Of acceptable risk: Science and the determination of safety. Los Altos, CA: W. Kaufmann.

Ludwig, B. (1997). Predicting the future: Have you considered using the Delphi methodology? Journal of Extension, 35(5), 1-4. Retrieved November 6, 2005, from http:/ /www.joe.org/joe/1997october/tt2. html

Medda, F. (2007). A game theory approach for the allocation of risks in transport public private partnerships. International Journal of Project Management, 25, 213-218.

Milner, M. (2004, March 21). Eurotunnel car traffic declines. The Guardian, p. 14.

Nevitt, P. K., \& Fabozzi, F. J. (2005). Project financing (7th ed.). London: Euromoney Books.

Newman, I., Ridenour, C. S., Newman, C., \& DeMarco, G. M. P. (2003). A typology of research purposes and its relationship to mixed methods. In A. Tashakkori \& C. Teddlie (Eds.), Hand-book of mixed methods in social and behavioral research (pp. 167-188). Thousand Oaks, CA: Sage.

$\mathrm{Ng}$, A., \& Loosemore, M. (2007). Risk allocation in the private provision of public infrastructure. International Journal of Project Management, 25, 66-76.

Nikolaidis, N., \& Roumboutsos, A. (2013). Ionia Odos Motorway, Greece. In A. Roumboutsos, S. Farrell, C. L. Liyanage \& R. Macario (Eds.), 2013 discussion papers. Part II case studies (pp. 55-61). Bari, Italy: Arti Grafiche Favia. 
Nisar, T. M. (2007). Risk management in public-private partnership contracts. Public Organization Review, 7(1), 1-19.

OECD. (2008). Public-private partnerships: In pursuit of risk sharing and value for money. Paris: Organisation for Economic Co-operation and Development Publishingo.

1005

Ono, R., \& Wedemeyer, D. J. (1994). Assessing the validity of the Delphi technique. Futures, 26(3), 289-304.

Onwuegbuzie, A. J., \& Leech, N. L. (2005). On becoming a pragmatic researcher: The importance of combining quantitative and qualitative research methodologies. International Journal of Social Research Methodology: Theory \& Practice, 8(5), 375-387.

Pellegrino, R., Vajdic, N., \& Carbonara, N. (2013). Real option theory for risk mitigation in transport PPPs. Built Environment Project and Asset Management, 3(2), 199-213.

1010 Pfeffer, D. J. (2010, December 28). The construction contract: Lump sum vs. cost plus. The New York Law Journalo, pp. 11-13.

Roumboutsos, A., \& Anagnostopoulos, K. (2008). Public private partnership projects in Greece: Risk ranking and preferred risk allocation. Construction Management and Economics, 26(7), 751-763.

Roumboutsos, A., Farrell, S., Liyanage, C. L., \& Macario, R. (Eds.). (2013). Discussion papers. Part II Case Studies. Bari, Italy: Arti Grafiche Favia.

1015 Roumboutsos, A., \& Nikolaidis, N. (2013). Olympia Odos Motorway, Greece. In A. Roumboutsos, S. Farrell, C. L. Liyanage \& R. Macario (Eds.), 2013 discussion papers. Part II case studies (pp. 81-89). Bari, Italy: Arti Grafiche Favia.

Rowe, G., \& Wright, G. (1999). The Delphi technique as a forecasting tool: Issues and analysis. International Journal of Forecasting, 15, 353-375.

Scheibe, M., Skutsch, M., \& Schofer, J. (1975). Experiments in Delphi methodology. In H. A. Linstone \& M. Turoff (Eds.), The Delphi method: Techniques and applications (pp. 262-287). Reading, MA: AddisonWesley Publishing Company.

Smith, N. J. (1996). Engineering project management. Oxford: Blackwell Scientific Publications.

Sumsion, T. (1998). The Delphi technique: An adaptive research tool. British Journal of Occupational Therapy, 61(4), 153-156.

Tang, L. Y., Shen, Q., \& Cheng, E. W. L. (2010). A review of studies on public-private partnership projects in the construction industry. International Journal of Project Management, 28, 683-694.

van Teijlingen, E., Pitchforth, E., Bishop, C., \& Russell, E. (2006). Delphi method and nominal group technique in family planning and reproductive health research. Journal of Family Planning and Reproductive Health Care, 32(4), 249-252.

Thomas, A. V., Kalidindi, S., \& Ananthanarayanan, K. (2003). Identification of risk factors and risk management strategies for BOT road projects in India. Indian Highways, 31(12), 53-75.

1030 Tiong, R. L. K. (1990). BOT projects: Risk and securities. Construction Management and Economics, 8, 315-328.

Voordijk, J. T. (2013). Coen Tunnel, The Netherlands. In A. Roumboutsos, S. Farrell, C. L. Liyanage \& R. Macario (Eds.), 2013 discussion papers. Part II case studies (pp. 39-46). Bari, Italy: Arti Grafiche Favia.

Voss, C., Tsikriktsis, N., \& Frohlich, M. (2002). Case research in operations management. International Journal of Operations \& Production Management, 22(2), 195-219.

1035 de Vries, P., \& Yehoue, E. B. (2013). The Routledge companion to public-private partnerships. New York, NY: Routledge.

Wei-hua, Y., \& Da-shuang, D. (2006). Concession decision model of BOT projects based on a real options approach. Proceedings of the international conference on management science and engineering (ICMSE '06).

Wibowo, A. (2004). Valuing guarantees in a BOT infrastructure projects. Engineering, Construction and Architectural Management, 11(6), 395-403.

Williams, P. L., \& Webb, C. (1994). The Delphi technique: An adaptive research tool. British Journal of Occupational Therapy, 61(4), 153-156.

Witkin, B. R., \& Altschuld, J. W. (1995). Planning and conducting needs assessment: A practical guide. Thousand Oaks, CA: Sage.

Woudenberg, F. (1991). An evaluation of Delphi. Technological Forecasting and Social Change, 40, 131-150.

1045 Yin, R. K. (1993). Applications of case study research. Applied Social Research Series. London: Sage.

Yin, R. K. (2009). Case study research, design and method (4th ed.). London: Sage. 